\title{
MORAL FOUNDATIONS OF COUNTERACTION \\ OF CRIMINALITY: ETHICAL QUESTIONS \\ OF CRIMINALISTICS
}

\section{Danshin M. V., Kostenko M. V.}

\section{INTRODUCTION}

The modern world is a technologically advanced space in which a person surrounded himself with objects of technology. They make up his leisure and way of life, the joy from acquisition and frustration from loss, even the manifestation of the creative abilities of a modern person takes into account laws and changes of the surrounding technosphere. The essence of man is transformed in the direction of gravitation not to nature, harmony and love, but to technicalization. A contradiction arises between the primordial standards of ethics and the need for the technical being of man, which entails an extensive class of ethical problems in the artificial world.

A significant increase in the technical capacity of society is accompanied by the fact that in a number of studies the object of influence is the person himself, which poses a certain threat to his health and existence. Nuclear physicists were the first to face problems of this kind. Now these risks and threats also affect the field of molecular biology, genetics, medicine, psychology, jurisprudence, etc. Diverse ethical problems in the most general form can be divided into the ethical problems of physics, biology, genetics, technology, law; the problems of ethics of the legal sciences of the criminal law cycle occupy a special place. Exactly these branches of law that are "attempted" and, to a large extent, they are somehow called upon to limit the realization of human and civil rights and freedoms. In this regard, the relationship between criminalistics as a science that is rightfully on the forefront of crime prevention and ethics is of particular interest.

The ethical problems of modern criminalistics are so urgent and significant that they cannot remain on the periphery of independent scientific research. In our opinion, the ethics of criminalistics is the moral basis of specific activity, the set of values principles adopted in this professional community, and concentrates in itself the social aspect of the purpose of criminalistics.

The problems of this issue were dealt with at different times by such scientists as L.Ye. Arotsker, R.S. Belkin, I.A. Bykhovsky, A.N. Vasiliev, G.F. Gorsky, Yu.A. Zarchin, N.A. Zakharchenko, A.S. Koblikov, L.D. Kokorev, Yu.A. Korenevsky, D.P. Kotov, A.M. Larin, S.G. Lyubichev, I.F. Panteleev, I.L. Petrukhin, A.R. Ratinov, M.S. Strogovich, etc. 
However, at present the questions of professional morality of criminalists are studied in the majority of cases when considering the admissibility of tactical techniques, and the problems of general trends in the correlation of criminalistics and ethics are only part of the analysis of the profession of the investigator, judge, prosecutor, etc., while the opportunities of other sciences come to the fore such as legal psychology or management science (NOT). Also, the analysis of modern forensic literature allows us to state the fact, that there is a certain one-sided tendency to consider the correlation of criminalistics and ethics only under the prism of the use of a new possible method of cognition in criminal proceedings (a detector of lies, hypnosis, astrology, etc.) with a margin from the complex study of moral began criminalistics, its functions in society and its purpose is as a legal science. Thus, the object of our research, based on the requirements for its volume, is the description of the connections of criminalistics and ethics, and the goal is to try to investigate the regulatory impact of morality on criminalistics science.

\section{Historical overview of problems}

In general, the term "ethics" comes from the ancient Greek word "ethos"a residence, a joint dwelling. In the IV century B.C. Aristotle designated the adjective "ethical" class of human virtues - character virtues in contrast to the virtues of reason - dianoethical. Aristotle formed a new noun ethica (ethics) to denote a science that studies virtues. Thus, ethics as science exists for more than 20 centuries. In the modern sense, ethics is a philosophical science that studies morality as one of the most important aspects of human life and society. If morality is an objectively existing specific phenomenon of public life, then ethics as a science studies morality, its essence, nature and structure, patterns of occurrence and development, a place in the system of other social relations, theoretically substantiates a certain moral system. Historically, the subject of ethics has changed significantly. It began to form as a school of human education, the teaching of his virtue, was considered and is being considered (by religious ideologists) as a man's call for the fulfillment of divine covenants that ensure the immortality of the person; is characterized as a doctrine of the indisputable debt and ways of its realization, as a science of the formation of a "new man" - the selfless builder of an absolutely fair public order, etc.

In domestic publications of the modern period, the definition of ethics as a science of the essence, the laws of the emergence and historical development of morality, the functions of morality, and the moral values of public life is predominant. In ethics, it is customary to separate two types of problems: 
theoretical problems about the nature and essence of morality and moral ethics - the doctrine of how a person should act, what principles and norms are required to be guided by. In the system of science there are, in particular, ethical axiology, which studies the problems of good and evil; deontology, exploring the problems of debt and due; descriptive ethics that studies the morality of a given society in sociological and historical aspects; genealogy of morality, historical ethics, sociology of morality, professional ethics.

Ethics as a science not only studies, generalizes and systematizes the principles and norms of morality operating in society, but also contributes to the development of moral ideas that meet historical needs to the maximum extent, thereby contributing to the improvement of society and man. Ethics as a science serves the social and economic progress of society, the affirmation of the principles of humanism and justice in it.

We fully share the opinion of R.S. Belkin that the area of connection of criminalistics and ethics is the development of means, methods and techniques of judicial research and the prevention of crimes and recommendations for their application in the practice of combating crime $^{1}$. It is in the field of counteraction to crime that there are problems that can be called with a certain degree of conventionality the ethical problems of criminalistics, although in some cases they are ethical problems not only and, perhaps, not so much criminalistic science as criminal justice a special kind of public human activity.

In general, criminalistics has arisen and develops as a science that can offer effective methods and techniques of counteracting crime. Unlike other independent complexes of the current scientific idea of the crime of criminalistics - a complex legal science of applied specific knowledge, which meets the modern tasks of counteracting crime and is designed to fully reflect the state policy of its implementation.

The field of connection of criminalistics and ethics is the development of means, methods and techniques of judicial research and prevention of crimes and the development of recommendations for their application in practice. Ethics, as one of the philosophical sciences, the science of morality, ethics, expresses and mediates certain social relations, connections of people. Being a public institution that performs the function of regulating human behavior ${ }^{2}$, as a form of public consciousness, a set of principles,

1 Белкин Р.С. Этические проблемы криминалистики. Повышение эффективности использования криминалистических методов и средств расследования преступлений: Труды Академии МВД СССР. Москва. 1985. С. 3.

Краткий словарь по этике. Москва. 1965. С. 226. 
rules, norms by which people are guided in their behavior ${ }^{3}$, morality, as an object of ethical science, serves as a necessary criterion for assessing criminalistic recommendations.

The moral standards, to which criminalistic techniques and means, forensic recommendations to practice must comply, are not only general, but also special in nature, reflecting the content and conditions of such a specific form of social practice as criminal proceedings ${ }^{4}$.

The question of the existence of judicial ethics as a special branch of this science, which studies the norms of behavior of participants in criminal proceedings, in legal literature, is generally solved positively. However, the very content of judicial ethics is understood differently. According to one group of scientists, judicial ethics is a private manifestation of general morality, the implementation of generally binding principles and norms in specific conditions of judicial research. So, M.S. Strogovich believed that "judicial ethics studies the application of general norms of morality in specific conditions of judicial and investigative activity, and does not create any special moral norms for judges, prosecutors, investigators, lawyers"s, that there are no such norms for lawyers as they do not exist for representatives of any other profession ${ }^{6}$. The views of G.F. Gorsky, L.D. Kokorev, D.P. Kotov, who claimed that there were specific norms of professional morality, but who saw in them only the result of applying general moral principles, taking into account the specifics of professional activity, are somewhat different from this position: "In any professional morality there cannot be any of its special moral standards that would not follow from general moral principles"7.

Finally, another group of scientists believes that judicial ethics includes not only general ethical standards, but, in addition, also specific moral principles ${ }^{8}$, inherent in the activities of an investigator, judge, lawyer ${ }^{9}$, complementing general moral principles, and in some cases restricting them ${ }^{10}$.

\footnotetext{
Философская энциклопедия. Москва. 1964. Т. 3. С 449.

4 Белкин Р.С. Курс криминалистики в 3 т. Т. 1: Общая теория криминалистики. Москва : Юристъ. 1997. С. 208-209.

5 Строгович М.С. Судебная этика, ее предмет и сущность. Сов. государство и право. 1971. № 12. С. 91.

6 Строгович М С. Проблемы судебной этики. Москва. 1974. С. 15.

7 Горский Г.Ф., Кокорев Л.Д., Котов Д.П. Судебная этика. Воронеж. 1973. С. 13-14.

8 Ароцкер Л.Е. Судебная этика. Соц. законность. 1969. № 9. С. 31.

9 Ароцкер Л.Е. Тактика и этика судебного допроса. Москва. 1968. С. 12.

10 Ратинов А., Зархин Ю. Следственная этика. Соц. законность. 1970. № 10. С. 35.
} 
The position of L.Ye. Arotsker, A.R. Ratinov and other scientists who share these views seem to us the most correct. L.Ye. Arotsker rightly pointed to the combination of general and special in the content of judicial ethics, the increasing role of the moral factor in criminal and civil proceedings. It is in judicial ethics, as in a variety of professional ethics, that complex moral norms find their implementation, which, unlike simple rules of morality, model "no longer individual actions, but behaviors, type of action, principle of life". The value of judicial ethics lies in the fact, that it shows how the regulatory impact of morality increases in the framework of professional activity, how "moral and professional rules, developed in collective experience, help a person through his work, concrete activity to more consistently and more deeply translate general prescriptions in behavior moral"11.

In this regard, we share the point of view of R.S. Belkin, who believes that professional morality, including all the general moral principles of society, enriches these principles with specific moral norms. The general moral principles are not only not limited to them, they are not reduced by these norms, but are supplemented by such ethical requirements, which are presented only to representatives of this profession. Professional morality acts as a complex of more binding, "stricter" moral rules than a complex of general moral principles. That is why criminalistics, developing its recommendations to the practice of combating crime, should ensure their compliance not only with general moral principles, but with the requirements of judicial ethical standards that reflect the ethical aspect of justice. This obliges forensic science to take into account the conditions of activity of a specific addressee of its recommendations. Thus, there is one more reason for the development, for example, of special tactical recommendations related to the area of judicial investigation, in contrast to recommendations intended for the investigator. The same was noted in the works of L.Ye. Arotsker, I.A. Bykhovsky and N.A. Zakharchenko, who distinguished between the ethics of judicial investigations and the ethics of conducting judicial actions ${ }^{12}$.

\section{The correlation of moral norms and tactics in the activity of the law enforcement}

The study of the moral aspects of criminalistics is especially necessary in modern conditions, when the task is to humanize public and state life, when a person is proclaimed the highest value by the Constitution of Ukraine,

\footnotetext{
11 Мораль и этическая теория. Москва. 1974. С. 79.

12 Быховский И., Захарченко Н. Этика проведения следственных действий. Сои. законность, 1973, №№ 11, 12. С. 33; 24.
} 
and guarantees of his rights and freedoms are brought to the forefront. And criminalistics - as a legal science has its own "object" of the person. The activity of the criminalist concerns the most important benefits, the interests of people, often connected with the invasion of their personal life, and sometimes with the restriction of rights, the adoption of decisions affecting the fate of a person. The investigation of crimes is a specific type of state activity, requiring the investigator of the appropriate strong-willed, psychological and moral qualities, which is due to the peculiarities of his tasks and the conditions for their achievement.

The specificity of the conditions of the investigator's activity, which leaves its mark on its moral content, is expressed in a number of provisions. The investigator is endowed with extensive authority, including the limitation of the fundamental rights and freedoms of person and citizen. $\mathrm{He}$ is a representative of the authority, authorized to apply state coercive measures. According to the law, an investigator is independent in conducting the investigation, when making the most important decisions. He leads the investigation in conditions of inadmissibility of disclosure of the data of the preliminary investigation and, with some exceptions, individually. He independently makes decisions and bears personal responsibility for them. All professional activities of the investigator take place in communication with people who are somehow involved in crimes or suffering grief, stress in connection with the crime, often in the context of counteraction to the investigation, the struggle of opposite interests. The investigator is bound by strict terms of investigation and currently works in many cases with overstrain of physical and spiritual forces due to excessive workloads.

Thus, we can conclude that the investigator must have high moral and psychological qualities, and moral flaws in the personality and behavior of the investigator can lead to dangerous consequences. In his activity, the investigator is guided by three types of rules: procedural, criminalistic and moral. Procedural norms indicate what exactly, in what forms, in what order the investigator should do, carrying out the investigation. The recommendations developed by forensic science help the investigator to identify a tactical line, to find techniques and methods that can most effectively carry out the tasks of the preliminary investigation: quickly and fully solve the crime and expose the perpetrators. Moral norms make it possible to assess the admissibility of certain methods of investigation from a moral point of view. Of course, all kinds of rules are in close connection with each other and should not be in contradiction, although the law prevails among them, which is presumed to be highly moral and expedient. 
The investigator, as A.S. Koblikov correctly noted in his study of legal ethics, bears personal moral responsibility for the tasks of the preliminary investigation, his professional duty. He must be objective, impartial, fair, humane and vigilant. In his official communication, the investigator must observe restraint, poise and correctness. In the process of investigating a crime, the investigator enters into a system of moral relations with a wide range of citizens who are in one form or another related to the crime or criminal proceedings. These are citizens interested in the outcome of the case, defending their rights and interests, that is, the participants in the process. The law includes the accused, the suspect, the victim, their representatives, the defense of the accused, the civil plaintiff, the civil defendant and their representatives to this category of participants. It is in relation to these persons that the investigator first of all has moral rights and moral duties in the performance of his functions. Another group includes other participants in criminal proceedings: witnesses, experts, interpreters, official witnesses, experts, other persons involved in the case usually in the interest of assisting the investigation or in connection with the organization of investigative actions (persons who are unrelated to the crime, for whom a search or seizure is carried out, persons presented as part of the group together with the identifying suspect, participating in the investigative experiment, etc.). The investigator's relations with the participants of the process and other persons, the powers of the investigator, the legal status of the citizens affected by the investigator's activities, are regulated by criminal procedure legislation and the norms of a number of other branches of law. The degree of their settlement by law varies. All the activities of the investigator, who performs his functions among citizens in the process of continuous communication with them, are subject to uniform moral principles and norms. The moral principles of the preliminary investigation, which are directly reflected in the criminal procedure legislation or stipulated by general principles and moral standards, irrespective of any type of activity, determine the moral content of the relationship of the investigator and all persons involved in the case. The ratio of moral standards and tactics in the activities of the investigator determines to a large extent the nature of his relationship with the persons involved in the case. Procedural rules, their entire system, not only regulate the order of the investigation, its form, but also underlie the determination of the most effective methods of investigation, affect the observance of its moral principles. In other words, the criminal procedure law forms the basis of both the development 
of tactical recommendations and the observance of ethical requirements in crime investigation activities ${ }^{13}$.

The correlation of recommendations of investigative tactics with legal and moral norms is one of the actual theoretical and practical questions. Tactical recommendations and the general provisions of the investigative tactics underlying them, theoretical concepts cannot be in conflict with the norms of law and the requirements of morality. Investigative activity for all its specifics cannot fail to obey the same moral standards for the whole society.

Analyzing the problem of the relationship between criminalistics and ethics can be faced in some literary sources with attempts to deny individual criminalistic recommendations under the pretext that they are allegedly contrary to the concepts of ethic and morality. Using one or another inaccurate or unsuccessful term and without going into the essence of the issue, the authors of such works declare, for example, the legitimate impact on the moral and emotional aspects of the person under investigation as unacceptable from the point of view of morality, thus artificially finding a contradiction between legitimacy and legitimate tactics, on the one hand, and moral principles - on the other. "To this wrong reasoning, what is fully applicable is what is said about the break in the theoretical and practical attitude to the object of research - morality - in ethical science, where such a gap leads "to two traditional diseases: to the ancient powerlessness of formalism, trying by means of speculative categorization, ignoring the data on the real moral behavior of people, to solve all ethical problems, and to sentimental, preaching moralization, which, addressing moral norms, can offer nothing but their preaching, without any serious, scientific justification, without understanding objectively occurring moral processes, their internal contradictions". So, R.S. Belkin correctly notes that "such a "preaching moralization", of course, only slows down the development and implementation of sound and legitimate criminalistic recommendations in practice and objectively damages the cause of the fight against crime, disarming investigators and judges. It is clear that the true interaction of forensic science and ethics can have nothing in common with such a phenomenon, which, incidentally, does not contribute to the strengthening of the moral principles of legal proceedings". Sometimes inadmissible methods of obtaining evidence are propagated in print under the guise of combating "backward, conservative" views and popularizing "nonstandard" (in the sense of progressive) investigation methods and techniques.

13 Кобликов А.С. Юридическая этика : учебник для вузов. 2-е изд., изм. Москва : Норма, 2004. C. $80-81$. 
So, the practice of using the biorhythm effect during interrogation of suspects and accused is described, when the investigator, with the help of a sports psychologist, determined the days of the psychophysiological vulnerability of the accused and it was on these days that the accused was recognized. Attempts are being made to attract psychics to solve crimes. The experience of using sorcerers and sorceresses (they are more softly referred to as possessors and possessors) to solve serious crimes is described. There are hints of the desirability of using hypnosis during interrogations. If we soberly evaluate the essence of these "non-standard methods", supposedly based on modern science, then in the end they come down to obtaining evidence favorable to the investigator, and mainly confessing the accused "by all means". These methods have long been "standard", in essence they are methods of the inquisition process. No one is obliged to testify against himself. The extortion of the accused's confession is in a "flashy" contradiction with this fundamental legal and moral norm. It is unacceptable and contrary to the law to practice the testimony of any person against his will and desire, whether he is an accused, a victim or a witness, by violence, threats, or deception.

Thus, evaluating an attempt to rely on clairvoyance and paravitdiagnostics in the investigation, A.R. Ratinov and V.N. Volkov, not without reason, come to the conclusion that the use of the help of dubious "consultants" and assistant predictors most likely points to the professional inconsistency of those who lead the investigation ${ }^{14}$.

The moral content of the investigator's relations with the accused, the suspect, the defense of the accused and other participants in the process is determined primarily by the impeccable observance of the norms of morality by the investigator. The moral climate of the investigation depends on the degree to which a person conducting the investigation has consistently observed the legal and moral norms. Activity, objectivity and impartiality, humanity, justice, impeccable honesty, high culture of communication with strict observance of the legality, rights and interests of the persons involved in the case are the most important moral requirements for the investigator.

Finally, attention should be paid to the need for the investigator to strictly observe correctness, endurance and tact in communicating with persons involved in the case, regardless of what position they occupy in the case, what emotions the investigator's personality and behavior cause. D.P. Kotov faithfully writes about this: "In relation to any person - a dangerous criminal and an ordinary brawler, recidivist; and a domestic squabble, injured

14 Социалистическая законность. 1991. № 8. С. 31. 
and simply offended - the persons involved in the criminal proceedings are required to be as staunch, tactful, cold-blooded, collected, calm, correct and purposeful in carrying out the tasks of the legal proceedings. And no matter how great the emotional and mental stress is, no matter how hard it is to restrain anger towards the killer, rapist, robber, disruption is unacceptable as well as threats, rudeness, deceit are unacceptable, whatever reasons and reasons they may be explained"15. Unfortunately, this topic is not particularly popular among the analyzed problems of counteraction of crime using the possibilities of criminalistic science, despite its rather acute practical relevance in modern Ukraine. Although there has already been a need to reconsider some of the entrenched views that tactically encouraged the investigator to use any tactical means of counteracting crime despite doubts about its moral purity, under the pretext of the alleged hopeless break-up of scientific dogmas from life, from the real investigative practice (R.S. Belkin). In our opinion it is necessary to formulate a certain theoretical evaluation mechanism, which will allow to construct a clear comprehensive model of understanding, on the one hand, of the modern conditions of law enforcement agencies' work (without denying its real extreme conditions: the equipment and professionalism of criminals, the acute shortage of investigative time, the lack of necessary forces and means from law enforcement agencies, the most powerful pressure from criminals and his "lobby" on employees, etc.) and, on the other hand, the formulation by the Legislator of a clear multilevel state conceptual policy (expressed in a modern complex program) aimed at counteracting crime in the country for the near and long term of building a legal state in Ukraine. Without the resolution of these problems, it is impossible to solve the question of admissibility or there is no certain criminalistic reception or means from the standpoint of public morality.

\section{CONCLUSIONS}

Summing up a definite result, we consider it possible to state that ethics as one of the philosophical sciences - the science of morality, expresses and mediates certain social relations, the connections of people. Being a social institution that performs the function of regulating human behavior, a form of public consciousness, a set of principles, rules, norms that people are guided in their behavior, morality, as the subject of ethical science, serves as a necessary criterion for the admissibility of the application of criminalistic recommendations in

15 Кокорев Л.Д., Котов Д.П. Этика уголовного процесса : учебное пособие. Воронеж. 1993. C. 46. 
practice. The requirement of legality of means and methods of judicial research and prevention of crime is supplemented by the requirement of their ethics, compliance with the principles of public morality ${ }^{16}$. These requirements may not conflict with each other, nor may they conflict with the principles of legality and expediency. As R.S. Belkin correctly noted, "expedient in criminalistics is recognized only that legally, and lawful always should be ethic, moral. The possibility of various (within the framework of the law) options for actions, behavior of the investigator, operative worker, judge is justified by criminalistics as a choice of a morally permissible option" 17 .

In modern conditions of counteracting crime, the law enforcement agency needs an increasing concentration of all its forces, knowledge and skills in order to effectively confront all the challenges of today's reality. In this regard, professional knowledge about the mechanism of criminal activity, methods of crime, the identity of the criminal, his psychotypes, typical behavior of the criminal in court, methods of counteraction to investigation and judicial review of the case, etc. is of special importance. Quite often in this area the employee lacks knowledge and practical experience. It is possible to fill this gap with the most substantive criminalistic study of the "various methods of criminals", taking into account their criminal specialization and the implementation of the data in practice. Today, without knowing the criminal, with his complex psychological world and motivation for behavior, it is practically impossible to solve the main task of criminalistics to assist law enforcement agencies in countering crime. Concrete knowledge is required, especially in view of criminal specialization. Otherwise, criminalistics can lag significantly behind the needs of practice.

Activities for the disclosure and investigation of crimes acts as the opposite of criminal activity and is largely secondary to it. It includes a number of areas, depending on the tasks of combating crime. Among them, criminal activities for the disclosure and investigation of crimes, activities for the judicial review of criminal cases, expert and criminalistic activities, criminalistic preventive activities, operational and search activities are particularly highlighted. All these activities are completely or partially the objects of criminalistic study.

\footnotetext{
16 Белкин Р.С. Криминалистика: проблемы сегодняшнего дня. Злободневные вопросы российской криминалистики. Москва: Издательство НОРМА (Издательская группа НОРМА-ИНФРА-М). 2001. С. 92.

17 Даньшин М.В. Роль науки в современном образовании и формировании личности. Наука $і$ соиіальні проблеми суспільства: трансформація иінностей у сучасному світі: матеріали VII Міжнародної науково-практичної конференції (7 червня 2013 р., м. Харків) / від. ред. І.В. Карпенко. Харків : ХНУ імені В.Н. Каразіна, 2013. С. 21.
} 
The activity on disclosure and investigation of crimes can be considered as a complex dynamic managed social system, which includes the following elements: the object of activity; the purpose and tasks of activity; subjects of activity; actions, receptions, methods of activity; place, time and environment of activity; results of activity.

The main object of the activity for the disclosure and investigation of crimes is criminal activity, which includes actions to prepare, commit a crime, counteract its disclosure and investigate. This object determines the information nature of the activity in question, its focus on the search, receipt and use of criminalistic information, in which the main place is taken by evidentiary information.

It should be recalled that historically the emergence of criminalistics is due to the fact that researchers in the field of criminal process, analyzing such an object of knowledge as criminal activity, revealed a certain complex of knowledge that were no longer criminal procedural. As a result, this scattered information was summarized by Austrian scientists Hans Gross, and the new branch of scientific knowledge was called "criminalistics". $\mathrm{H}$. Gross, justifying the system of criminalistic science, paid considerable attention to criminals and crimes. Whole chapters of his famous work are devoted to various tricks used by criminals, their thieving language, as well as issues such as "changing appearance, false testimony of rank and name, simulating illnesses and physical ailments, secret signs among criminals, a dictionary of thieves's language, superstition in relation to objects left at the crime scene, superstition regarding things carried by oneself', and some others ${ }^{18}$. Subsequently, generalization and systematization of the newly obtained information was carried out at the level of a logically organized knowledge system, capable of explaining the numerous phenomena associated with the mechanism of tracing during the preparation, commission and concealment of a crime, and then with the criminalistic activity of the participants in the criminal process. The works of E. Anushat, A. Weingart, V.I. Gromov, Yu.G. Manns, S.M. Potapov, P.S. Semenovsky, S.N. Tregubov, I.N. Yakimov made an invaluable contribution to understanding and researching the problems, as well as other prominent scientists of the period of the formation of criminalistics as a science.

But even then, the well-known criminalist scientists have never stated that it is necessary to use the same arsenal of methods to investigate crimes as was used in its commission. Inappropriate methods that are immoral are

18 Гросс Г. Руководство для судебных следователей как система криминалистики. Новое изд., перепеч. с изд. 1908 г. Москва, ЛексЭст, 2002. 1088 с. 
not morally defensible. Then they were what we call illegal. Therefore, we believe that it is appropriate now to say that there is a long-standing need to review all the bases of the fight against crime with a view to their ethics.

Also, when analyzing the problems stated by us, it is necessary to point to another modern scientific problem. This is a problem of morality and criminalistics in the aspect of identifying the very essence of criminalistics and trends in its change and development. So, there are different points of view about the nature and the subject of criminalistics. All concepts, concerning technical essence, not legal nature or vice versa, have the right to life, however, such mechanical distribution of the unified science into two diverse camps, on legal and not legal, is a restriction of further development of criminalistics and artificial narrowing of the sphere of practical recommendations of it. And it is the ethical and moral component of it that makes us consider criminalistics as a legal science. The reason for considering criminalistics as a purely technical science, in our opinion, lies precisely in its content at the time of police or criminal technology, and also is caused by the desire to dissociate from criminal-procedural science into an independent field of knowledge and create its own subject and methods of research. Significant is also the significant influence on the criminalistics of natural and technical sciences (mathematics, physics, chemistry, biology, etc.), the use of methods and techniques of these sciences. At that time, the views of criminal scientists were progressive and contributed to the development of a new science.

Thus, a subjective understanding of the philosophy of criminalistics and its nature, its moral principles, as well as tracking the processes of constant and continuous search by criminalistics of their own place in the system of existing scientific knowledge, allows us taking into account the requirements for the volume of our publication, to try to formulate certain current contemporary scientific and theoretical problems of this science are related to morality.

First, criminalistics is a dynamically developing legal science in the system of criminal law sciences, which ensures the effective functioning of criminal law and the criminal process. Secondly, today a particularly priority area for the development of criminalistic science is to find its own place in the system of the cycle of legal sciences and establish clear boundaries in the entire system of modern scientific knowledge. Thirdly, the resolution of this complex of issues will help relieve tension in heated discussions and disagreements among scientists regarding the nature and subject of criminalistics. Subsequently, this is precisely what will have a beneficial effect on the implementation of future independent comprehensive and multi-vector studies of individual 
aspects of the methodological foundations of criminalistics, and will also help, in particular, to correctly analyze the process of forming the language of criminalistics and systematize the already accumulated rich terminological apparatus of science. In this regard, we share the view that criminalistics from a highly specialized branch of knowledge that serves the investigation and disclosure of crimes has become a methodological science, which has been investigating law enforcement activities on a general scale. Therefore, it should be considered and developed as a discipline of the methodological level in an inseparable connection with the general methodology of law, the theory of judicial evidence and forensic examination.

It specially should be noted in this connection that the separate current scientific and theoretical views regarding the issues raised by us, unfortunately, do not fully reflect the essence, purpose and the very spirit of the science of criminalistics. So, in the works of some modern criminalistic scientists, in particular, devoted to the fundamental issues of determining the place of forensics in the system of modern legal sciences, there is a clear ambiguity and fragmentation in the substantiation of their own views and thoughts about this. On the basis of this, a large and rather controversial array of already independent other theoretical theories and assumptions is created, which as a result can serve only a separate secondary and partial goals of science (a prominent Russian criminalist R.S. Belkin called them "phantoms" of criminalistics - some illusory concepts and theories of science, which only confuse with their pseudoscientific provisions) and now extremely negatively affect the general process of its development.

Thereby, summarizing a certain result, we can state that at the present stage of the transformation of scientific knowledge, the current directions of the development of criminalistics are the issues of improving its methodological foundations, namely: detailed analysis of the whole set of historical and scientific aspects of the formation of criminalistics as a science; studying the nature of this science on the basis of the definition of criminalistics in the system of modern scientific knowledge; finding the place of science in the modern system of legal sciences; analyzing the long-standing urgent problems of the modern educational course of criminalistics in specialized and non-specialized higher educational institutions; studying the whole set of connections of criminalistics and theory of operational search activity; criminal analysis and forecast of modern problems and prospects of formation and independent development of the science of the OSA. An independent prospective problem in this series are the questions of the ethics of criminalistics, the moral foundations 
of the science of the disclosure and investigation of crimes. Resolving this particular set of pressing scientific and theoretical problems of modern forensics, precisely in their system, will significantly optimize the practice of counteraction of crime at the present stage of toughening the criminal situation in the world.

\section{SUMMARY}

The publication analyzes the communication area of criminalistics and ethics as components of a unified process of counteraction and containment of crime. The authors highlight various views of scientists on the content of judicial ethics, and emphasize the comparative analysis of modern concepts with the views and dogmas of predecessors, representatives of traditional generally accepted scientific schools. The moral norms that modern criminalistics receptions, methods and means must conform to on the basis of universal values and norms are investigated very carefully. The issues of moral and ethical principles of the implementation of certain legal actions aimed at ensuring justice, but in fact aimed at the infringement of individual human rights and freedoms are analyzed. As a result of the work, researchers come to certain positions and conclusions that have important both scientific and practical value. The work is written by a scientific team that has in its arsenal of opportunities the experience of teaching, research and practical experience in law enforcement agencies of Ukraine. The content will be interesting to lawyers, sociologists, conflict managers, philosophers, and everyone who cares about the current trends in the development of forensic science and the problems of containing modern crime.

\section{REFERENCES}

1. Белкин Р.С. Этические проблемы криминалистики. Повышение эффективности использования криминалистических методов и средств расследования преступлений: Труды Академии МВД СССР. Москва, 1985. C. 3-14.

2. Краткий словарь по этике. Москва, 1965. 312 с.

3. Философская энциклопедия. Москва, 1964, т. 3. 765 с.

4. Белкин Р.С. Курс криминалистики в 3 т. Т. 1: Общая теория криминалистики. Москва : Юристъ, 1997. 408 с.

5. Строгович М.С. Судебная этика, ее предмет и сущность. Сов. государство и право, 1971, № 12. С. 89-99.

6. Строгович М.С. Проблемы судебной этики. Москва, 1974. С. 217.

7. Горский Г.Ф., Кокорев Л.Д., Котов Д.П. Судебная этика. Воронеж, 1973. 164 с. 
8. Ароцкер Л.Е. Судебная этика. Соц. законность, 1969, № 9. С. 24-36.

9. Ароцкер Л.Е. Тактика и этика судебного допроса. Москва, 1968. C. 9-18.

10. Ратинов А., Зархин Ю. Следственная этика. Соц. законность. 1970 , № 10. C. 29-41.

11. Мораль и этическая теория. Москва, 1974. 221 с.

12. Быховский И., Захарченко Н. Этика проведения следственных действий. Соц. законность, 1973. №№ 11, 12.

13. Кобликов А.С. Юридическая этика : учебник для вузов. 2-е изд., изм. Москва : Норма, 2004. 176 с.

14. Социалистическая законность. 1991. № 8. С. 31.

15.Кокорев Л.Д., Котов Д.П. Этика уголовного процесса : учебное пособие. Воронеж, 1993. 316 с.

16. Белкин Р.С. Криминалистика: проблемы сегодняшнего дня. Злободневные вопросы российской криминалистики. Москва : Издательство НОРМА (Издательская группа НОРМА-ИНФРА-М), 2001. $240 \mathrm{c}$.

17. Даньшин М.В. Роль науки в современном образовании и формировании личности. Наука $і$ соціальні проблеми суспільства: трансформація цінностей у сучасному світі : матеріали VII Міжнародної науково-практичної конференції (7 червня 2013 р., м. Харків) / від. ред. I.В. Карпенко. Харків : ХНУ імені В.Н. Каразіна, 2013. С. 21.

18. Гросс Г. Руководство для судебных следователей как система криминалистики. Новое изд., перепеч. с изд. 1908 г. Москва, ЛексЭст, 2002. $1088 \mathrm{c}$.

\section{Information about authors:}

Danshin M. V.,

Doctor of Law, Professor, Professor of the Department of Law Military Law Institute of Yaroslav Mudryi National Law University 77, Pushkinskaya str., Kharkiv, Ukraine

Kostenko M. V., Candidate of Legal Sciences, Associate Professor of the Department of Criminalistics Yaroslav Mudryi National Law University 77, Pushkinskaya str., Kharkiv, Ukraine

DOI https://doi.org/10.30525/978-9934-588-43-3/2.2 